\title{
EMP1 wt Allele
}

National Cancer Institute

\section{Source}

National Cancer Institute. EMP1 wt Allele. NCI Thesaurus. Code C52346.

Human EMP1 wild-type allele is located in the vicinity of 12 p12.3 and is approximately 20 $\mathrm{kb}$ in length. This allele, which encodes epithelial membrane protein 1 , is involved in both cell-cell interactions and in the control of cellular proliferation. 